\title{
Conditions and Issues Park of Community Reading in Palembang
}

\author{
Azizah Husin \\ Sriwijaya University \\ Palembang, Indonesia \\ Azizahhusin66@yahoo.Co.Id
}

\begin{abstract}
The need for community reading interest to be dug and developed. By reading people can know and understand many things. It is through the institution or community or even individual reading interests should be noted and supported or motivated. This paper aims to describe the condition and problems of Park of Community Reading (TBM) in the city of Palembang. The public library is a place to accommodate and meet the needs of people to read. The public library provided to foster and channel the interest in reading. The goal is that society becomes a society like of reading (learning society). The study is a qualitative analysis of the facts on the field using interview, observation, and documentation. The existing problems in the public library are reading park grows through the PKBM (Learning Centre Society) / LCS) and the LCS program. One of PKBM program is Early Childhood Education.Reading activity is doing a function of good leisure time activities of the mothers who wait for their children when learning in early childhood. As conclusion is TBM / Park of Community Reading are not growing and developing in accordance with the primary objective.
\end{abstract}

Keyword: public library, LCS, reading, TBM

\section{I.INTRODUCTION}

Reading is essential for every human being to have the knowledge and skills in many areas of life, and make the increased life. People who read a lot and a lot of learning will increase the quality and degree than previously [1]. The quality of a nation can be reflected also by how much interest in reading a society. Interest in reading the Indonesian nation was $0.001 \%$. Indonesia in the Asian Reading level is above Laos and Vietnam / Burma. This men's Indonesian low in reading interest.

Various methods are used to foster interest in reading. The government provides funding for the establishment of reading community. But the problem there is Park of Community Reading (Taman Bacaan Masyarakat) does not develop as expected. TBM is less influential on the development of the public interest [2, 3].

TBM is a place that provides books and the like with the expectation/goal of keeping people interested and lead as well as generate interest in reading so that people like reading and eager to learn [4].
Digging interest in reading is not an easy task because it involves a less culture-oriented for society likes to read. Institutions that are already available that deal specifically to develop an interest in reading the great libraries such as libraries regional, national, and universities, including public reading.

TBM is provided to the general public with various ages and knows no boundaries of race, religion, ethnicity, politics and so forth [5]. Libraries should be accessible, attractive, pleasant, comfortable, provided enough books, well-managed. Required an enabling condition can dig up interest in reading through an interest in the TBM itself. Conditions allowing became public appeal if: the location of the library in the open room, the library room easily visible, arrangement of interesting books, books that are available to accommodate the needs of reading of all ages and groups of interest in reading, the books are there to draw attention to views and read, the number of insufficient availability of books, the books vary from all kinds of books, books that are available in a state that is maintained clean and attractive [6,7]. From some of the above requirements, how the condition of public reading in Palembang?

\section{RESEARCH AND DISCUSSION}

Public reading in Palembang enrolled in Dikdispora totaled 42 TBM. TBM is spread in the districts in the city of Palembang. Most of the TBM in early childhood school, so one PAUD has one TBM.

Of the 42 TBMs were registered only 2 TBM entered the category small TBM (community library). Location of these TBM is in the crowd where people passing perform daily activities. The building is quite spacious and easily recognizable and visible. Availability of this many books of TBM and complete with a collection of books that consist of entertainment, skill and general knowledge. Structuring the book to attract enough entrants to touch and read and borrow the book. Size of the building just enough to display the books.

Impressions book is quite interesting, the book laid out with attractive looks page book covers various entertainment, stories of children, adolescents, novels, fiction, skills and other knowledge. The number of books is quite a lot with many different variations, position and clear strategic location easily seen because of its position on the roadside. In addition, there 
are 2 people labor are present every day. One of the owners of this TBM is an independent private foundation managed by a foundation based in Bogor. Moving to make community learn and increase public interest and aims to make the public love to read. The clientele is quite a lot, and the book flows smoothly because the borrower enthusiasm for reading, and upon completion be returned within a certain period. The physical condition of good books is not shabby, up to date, and a diverse and interesting. The total collection is also quite.

PKBM (Community Learning Activity Centers) where the main activities are early childhood, Equality, and TBM. TBM is joined with PAUD which provides books that exist cuisine menu and religious books/prayer, as well as books for equalization as package A, B, C. Method of lending is done by offering to the participants in the study of equalization (functional equality), participate borrowed the book collections of the TBM, so book revolving [8]. Likewise, for the mothers waiting for their children taking part in early childhood learning, manager PKBM provide books that match the tastes of mothers note magazines, recipes, story books, prayer books, and the like [9]. TBM has many collections of interesting books and varied and in accordance with the needs of the consumer. Business cooperation with the library and a bookshop/publisher. However, the collection of the books are still needed to be increased. Loan period 2 weeks for one magazine is Rp. 2000. This way is charming proved to flow more books, and collections managers can buy a new one again. Book on PKBM is more varied and new. The steps are cooperation with libraries and bookstores.

Instead TBM, other physical conditions at the scene early childhood. The book is inside the room itself is small and the book is not playing, just arranged in one glass cupboard and not easily read the cover because of way arranging books. A number of titles do not reach the 300 titles. The book collection is not varied, less than meets the needs of audiences of all ages. Circulation of books is very low, almost no circulation of books. The book collection is not meeting the needs of society, especially for the mother.

For TBM arranging the books like these is far from the requirements as libraries that can motivate people to love reading. There TBM which has a reading room, but her book is only located in one wall wood cabinets and does not deserve to be called a bookcase especially to display the collection. Total collections are not up to 40 titles, and books as well as magazines and newspapers, it is not worth reading, dusty, shabby and very old and not well maintained. The location is also adjacent to the PKBM. And there are even TBMs do not indicate where space is a collection of books (library space) and a reading room $[11,12]$.

Public reading room located in the PKBM has become a trend. Nearly 95\% Located at the location where PAUD is located. His room is in place to learn and play. Books are arranged in a bookcase or cabinet. Impressions book is not very aesthetically to potential readers. Based on interviews with managers of the TBM, the original purpose of the opening of the public reading in early childhood education is based on the use of leisure time for mother/parents in early childhood when waiting for school children. But in reality, it is not managed well. As, if the only requirement just that in early childhood there TBM. Vision and Mission of the establishment of the TBM are not clear.

Business TBM is also not clear who the actual, automatically managing early childhood education and early childhood education as a headmaster or managers [13]. Almost all TBM do not have any managers in particular. There is no management plan TBM. So TBM not functioning encourage interest in reading. The overall condition of the TBM in the city of Palembang as follows:

- Based on observations at several locations libraries, most of it was found that the location of the park reading not entered the category or condition of the founding of the TBM, it is not strategic. Place away from the crowds, hidden, do not look directly by the public

- Space libraries are less conducive for people to read, as it is located in the student study rooms, reading rooms are not designed specifically for a reading, bookshelf position is not organized to attract the reader's attention.

- His books are not worthy to be used again (worn, not up to date, torn). Displayed book is not a book of interest to inculcate interest in reading, but only a shabby book, a book only student paper which is not worth displayed

- A number of books are very few and less varied, and in this conditions are not worth reading.

Moreover, the book is not interesting, the books on display are also for school books. The arrangement does not meet either category. In conclusion condition of Palembang TBM less well. Far from the criteria of libraries in all aspects, location, reading room, books, structuring. Thus the public reading does not develop properly so that the low reading interest.

Interest in reading is a people ability. Intrest in reading can be seen in interested in the location, the space and the arrangement of the book. Further variations of the book, freshness, meet the needs of all ages, hospitality services.

Public reading (TBM), is an institution that operates as a container that holds and motivate people to read by providing reading books and has been regulated by law. The purpose of the libraries is to make the general public likes to read, and in the end, so people eager to learn. The book is contained science, knowledge, and science and information for the reader and is needed by the community. Structuring the book is a way to draw and can affect interest in reading so that people are interested to borrow and read it. As well as one of the motivations for reading, if arranging the book is not interesting not encourage someone to try to view or toward the bookshelf, much less willing to borrow and read.

Location TBM is crucial to people over and sightseeing books on display. It is likely they are willing to becoming libraries member. It was as early as one interested in reading, through the desire to touch a book that he felt attracted when he saw it. The location is away from the crowds causing people who know not extensive, because it does not look directly and 
not be in the crowd. Libraries should / better be in the hustle of society.

Terms of a good library is a library space raises people to feel comfortable to read, easily visible, bright, attractive, open, clean, and comfortable [14,15].The types and variety of books can influence the urge to borrow and read books that are available. The appeal of the book is a variable representing various ages, occupations, and skill and knowledge to read a book if according to his interests.

\section{CONCLUSIONS}

The condition of public reading in Palembang is still far from the expected public reading. Not reading the strategic location of the park, the rooms were used to join the room studying early childhood education, the arrangement of the book is less to attract attention, the number of books are very few, conditions in most of the books are not up to date, shabby, dusty, and not worth reading. Besides books there are less attract people to read it, they have barely touched the book to read. To readings suggested that the establishment of the TBM must be planned and surveyed first. and professionally done by considering the strategic location of the place of establishment libraries are easily seen in the crowd, the arrangement of books on display, variations in reading books, and more, so that the TBM will grow on both in terms of quantity aspect as well as quality.

\section{REFERENCES}

[1] Suryadi, A. (2009). People realize Learners. Bandung: Widya Script Press. FIPUPI Press
[2] Aisyah Didda Maulida, (2012). Community Library Management (TBM). BIP Library Mall Growing Interest In Community Reading. Indonesian education university. repository.upi.edu

[3] MONE. (2003). Guidelines for Management of Community Library (TBM). Jakarta.

[4] Tony Simbolon. (2013). Read Cultural Development Through Community Library (TBM) Sub-Directorate infrastructure development directorate of public education directorate early childhood education, non-formal and informal education and culture department

[5] Directorate of Public Education. (2010). CREATIVE Community Library. Pemendiknas.

[6] Sutarno, NS. (2006). Library and Society. Jakarta: Sagung Seto.

[7] Sutarno NS (2006). Library management: a practical approach. Jakarta: Sagung Seto. (Http://paudni.kemdiknas.go.id/wpcontent/uploads/2012/02/07.-Bantuan-Penguatan-TBM.pdf=Juni-2012) Partnership Strategy Community Library, (2010). Yogyakarta: Pustaka Mitsaq

[8] Sutarno, NS. (2008). Fostering Library Desa.Jakarta: Sagung Seto

[9] Martoatmojo, Karmidi. (2009). Services Library Materials. Jakarta: The Open University

[10] MONE (Ministry of Education). (2012). Technical Guidelines for Filing and Management of Community Library Public Space Year 2012 Jakarta: Directorate of Public Education, the Directorate General of Non-Formal and Informal Education

[11] Sagung Seto. (2006). One Century National Revival and Awakening Library 1908 -2008. Jakarta: Sagung Seto

[12] Tafrikhuddin. (2007). "Contributions Libraries as Information and Education Resource Center at the beginning of Islamic civilization" in the Journal of the Science Library and Informa Volume II, No. 2 (July December 2007)

[13] Lakshmi. (2008). "Understanding the Role and Function of TBM and the School Library" Paper presented at the Technical Training Community Library business / TBM and the School Library South Jakarta Administration City, July 22 to 24, 2008.

[14] Lasa, Hs. (2009). Dictionary of Librarianship Indonesia. Yogyakarta: Library Book Publisher. 